\title{
Cullet Manufacture Using the Cylindrical Induction Melter
}

by

D. H. Miller

Westinghouse Savannah River Company

Savannah River Site

Aiken, South Carolina 29808

This paper was prepared in connection with work done under the above contract number with the U.S.

Department of Energy. By acceptance of this paper, the publisher and/or recipient acknowledges the U.S.

Government's right to retain a nonexclusive, royalty-free license in and to any copyright covering this paper, along with the right to reproduce and to authorize others to reproduce all or part of the copyrighted paper. 


\section{DISCLAIMER}

This report was prepared as an account of work sponsored by an agency of the United States Government. Neither the United States Government nor any agency thereof, nor any of their employees, makes any warranty, express or implied, or assumes any legal liability or responsibility for the accuracy, completeness, or usefulness of any information, apparatus, product or process disclosed, or represents that its use would not infringe privately owned rights. Reference herein to any specific commercial product, process or service by trade name, trademark, manufacturer, or otherwise does not necessarily constitute or imply its endorsement, recommendation, or favoring by the United States Government or any agency thereof. The views and opinions of authors expressed herein do not necessarily state or reflect those of the United States Government or any agency thereof.

This report has been reproduced directly from the best available copy.

Available for sale to the public, in paper, from: U.S. Department of Commerce, National Technical Information Service, 5285 Port Royal Road, Springfield, VA 22161, phone: (800) 553-6847,

fax: (703) 605-6900

email: orders@ntis.fedworld.gov

online ordering: http://www.ntis.gov/ordering.htm

Available electronically at http://www.doe.gov/bridge Available for a processing fee to U.S. Department of Energy and its contractors, in paper, from: U.S. Department of Energy, Office of Scientific and Technical Information, P.O. Box 62, Oak Ridge, TN 37831-0062,

phone: (865)576-8401, fax: (865)576-5728

email: reportseadonis.osti.gov 


\section{DISCLAIMER}

Portions of this document may be illegible in electronic image products. Images are produced from the best available original document. 


\section{SAVANNAH RIVER TECHNOLOGY CENTER}

Date: $12 / 15 / 99$

TO: W. H. MARTIN, 730-2B

FROM: L. F. LANDO 704,

\section{CULLET MANUFACTURE USING THE AM/CM CYLINDRICAL INDUCTION MELTER}

The attached document describes the process employed in the Am/Cm Pilot Facility to prepare cullet in response to Task 1.01 of TTR-NMSS/SE-006. The cullet produced in the described manner has been used in the majority of process simulations conducted in the Pilot Facility. Please refer any questions you may have regarding the contents of this document to D. H. Miller (Ext. 7-7007)

\section{DISTRIBUTION}

J. T. Dahlstrom, 730-1B

A. W. Bowers, 704-10F

A. P. Giordano, 730-1B

A. P. Fellinger, 730-1B

N. H. Harkey, 730-1B

D. C. Witt, 704-1T

D. H. Miller, 704-1T

STI 703-43A (4) 
WSRC-TR-99-00466, Revision 0

\section{CULLET MANUFACTURE USING THE CYLINDRICAL INDUCTION MELTER (U)}

D. H. MILLER

Westinghouse Savannah River Company

Savannah River Site

Aiken, SC 29808

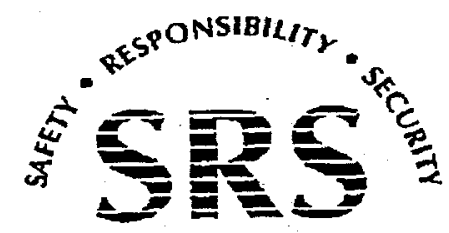

PREPARED FOR THE U.S. DEPARTMENT OF ENERGY UNDER CONTRACT NO. DE-AC09-96SR18500 


\section{DISCLAIMER}

This report was prepared by Westinghouse Savannah River Company (WSRC) for the United States Department of Energy under Contract No. DE-AC09-96SR18500 and is an account of work performed under that contract. Neither the United States Department of Energy, nor WSRC, nor any of their employees makes any warranty, expresses or implied, assumes any legal liability or responsibility for accuracy, completeness, or usefulness, of any information, apparatus, or product or process disclosed herein or represents that its use will not infringe privately owned rights. Reference herein to any specific commercial product, process, or service by trademark, name, manufacturer or otherwise does not necessarily constitute or imply endorsement, recommendation; or favoring of same by WSRC or by the United States Government or any agency thereof. The views and opinions of the authors expressed herein do not necessarily state or reflect those of the United States Government or any agency thereof. 
WSRC-TR-99-00466, Revision 0

ITS Tracking Number:

ITS-99-0100

Keywords: Americium, Curium,

Vitrification, Cullet

Retention: Permanent

\title{
CULLET MANUFACTURE USING THE CYLINDRICAL INDUCTION MELTER (U)
}

\author{
D. H. MILLER
}

Publication Date: 12/13/99

Westinghouse Savannah River Company

Savannah River Site

Aiken, SC 29808

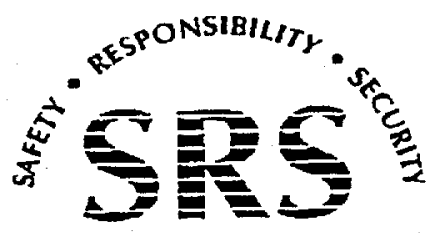

SAVANNAH RIVER SITE

PREPARED FOR THE U.S. DEPARTMENT OF ENERGY UNDER CONTRACT NO. DE-AC09-96SR18500 


\section{APPROVALS}

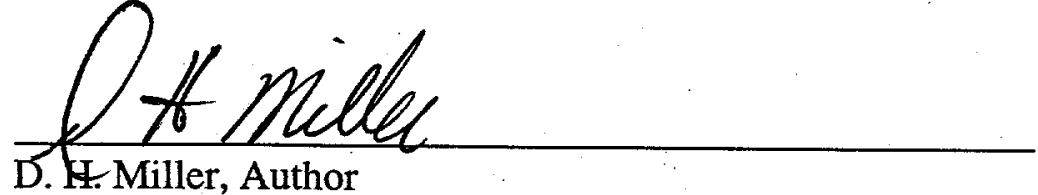

Immobilization Technology Section

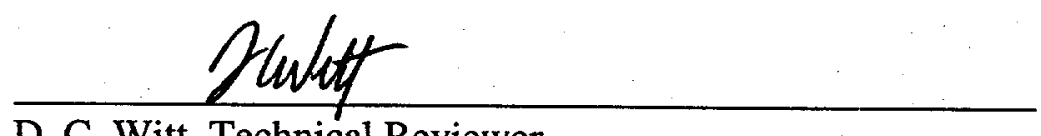

D. C. Witt, Technical Reviewer

Immobilization Technology Section

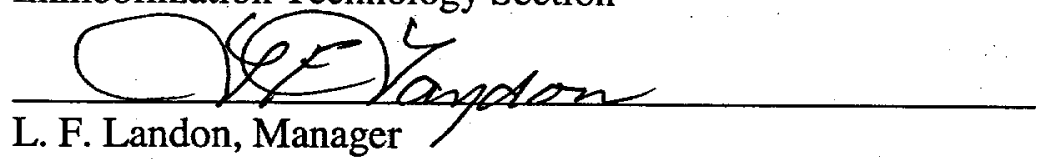

Immobilization Technology Section

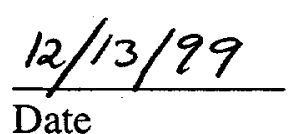

Date

$\frac{12 / 13 / 98}{\text { Date }}$ 


\section{TABLE OF CONTENTS}

INTRODUCTION

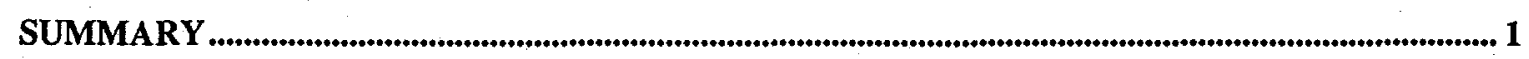

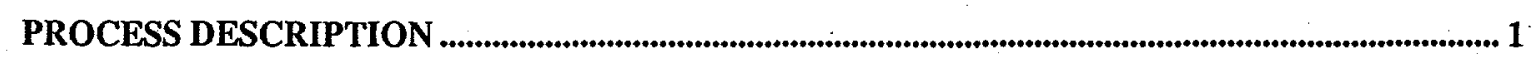

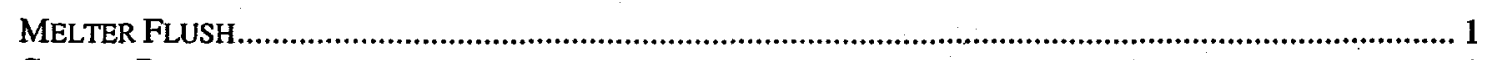

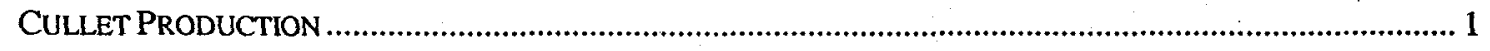

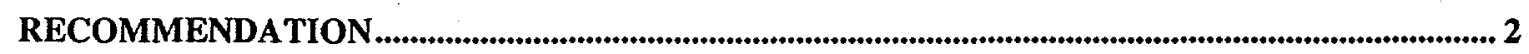

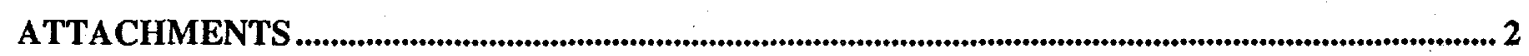

REFERENCES 
WSRC-TR-99-00466

Page 1 of 4

\section{INTRODUCTION}

The base process for vitrification of the Am/Cm solution stored in F-canyon uses $25 \mathrm{SrABS}$ cullet as the glass former. A small portion of the cullet used in the SRTC development work was purchased from Corning while the majority was made in the 5 inch Cylindrical Induction Melter (CIM5). Task 1.01 of TTR-NMSS/SE-006, Additional Am-Cm Process Development Studies, requested that a process for the glass former (cullet) fabrication be specified. This report provides the process details for $25 \mathrm{SrAB}$ cullet production thereby satisfying Task 1.01 .

\section{SUMMARY}

The CIM5 was used to produce $\sim 50 \mathrm{~kg}$ of cullet for use in TTR testing. Six runs were required to produce the quantity of cullet needed. Glass marbles previously purchased for use in the program were used to produce the cullet. The marbles were melted at $1500^{\circ} \mathrm{C}$ and the molten glass was quenched by pouring into water to produce cullet.

\section{PROCESS DESCRIPTION}

\section{Melter Flush}

Before the cullet runs were begun, the melter was flushed to clean out the residual glass from previous testing. This was accomplished by charging the melter with 2000 grams of $-14 /+30$ mesh $25 \mathrm{SrABS}$ frit. The frit was from Ferro Lot Number 721617 . The material was heated at approximately 10 to $15^{\circ} \mathrm{C} / \mathrm{min}$ as indicated by the bed thermocouple (T3C). When a set point of $1500^{\circ} \mathrm{C}$. was reached, the bubbler was inserted at a level $l^{\prime \prime}$ from the bottom of the melter. Argon flow was initiated at $1.5 \mathrm{scfh}$ and an addition of 500 grams of $1 / 4$ inch $25 \mathrm{SrABS}$ glass beads was made. When the temperature of the bed had recovered, an additional 500 gram charge of beads was made. This process was repeated until the melter contained $6 \mathrm{~kg}$ of glass. An interlock occurred during the cycle because of a faulty temperature indication, but temperatures were quickly recovered. A thirty minute soak was used before the pouring cycle was begun. A total of 4 buckets of water were used to capture the glass from the pour. The glass was allowed to cool and was sampled. The material appeared very uniform with only trace amounts of colored glass found in the first portions of the pour. This material was isolated and saved for possible future use.

\section{Cullet Production}

After flushing the melter, the cullet for the TTR testing was made over three days, with each run consisting of two $6 \mathrm{~kg}$ charges and two $6 \mathrm{~kg}$ pours. A typical run is described below. An initial charge of 6000 grams of $25 \mathrm{SrABS}$ marbles was made to the melter. The $3 / 8^{\prime \prime}$ marbles were produced by Corning on purchase order $A B 93818 \mathrm{~N}$. The bubbler was placed in the melter at $3 / 4$ 
above the bottom of the vessel. The bed thermocouple (T3C) was located 2" off the bottom of the vessel. After a short drying time to remove moisture, the power was ramped on the vessel and vessel bottom to obtain a 10 to $15^{\circ} \mathrm{C} / \mathrm{min}$ increase in temperature. When the bed reached $750^{\circ} \mathrm{C}$, the cover was placed over the melter to reduce radiant heat loss. When the bed thermocouple reached $1500^{\circ} \mathrm{C}$, a $1.5 \mathrm{scfh}$ flow of argon was introduced through the bubbler. Drain tube power was then initiated at $0.26 \mathrm{kw}$ and ramped at approximately $40^{\circ} \mathrm{C} / \mathrm{min}$. Thirty minutes after the bubbler initiation, the pour cycle was begun. A three gallon stainless steel bucket was filled with 2 gallons of deionized water to catch the glass stream. The buckets were changed when the water started to boil vigorously. This occurred in approximately 10 minutes when 1200- 1400 grams of glass had been poured. A total of 4 buckets were used for each melter charge. Glass accumulated in the bucket was occasionally stirred to prevent a large mound from building up. Pour rates were approximately $10-12 \mathrm{~kg} / \mathrm{hr}$, with the rate dropping toward the end of the pour due to reduced static head. When the glass started dripping, tip cooling air was applied and the bubbler was removed. With power levels unchanged, 6000 grams of marbles were added to the melter. The melter was covered immediately. When the temperatures had recovered to $1500^{\circ} \mathrm{C}$, the bubbler was inserted and argon flow was initiated. Thirty minutes later the second pour cycle was started. The glass was again caught in 4 buckets of deionized water. After pouring, the melter was cooled using the auto cool down cycle. Samples for analysis were collected from each of the pour cycles.

\section{RECOMMENDATION}

The cullet produced in this campaign has been used successfully in numerous TTR tests. This process produces a cullet where $100 \%$ of the cullet will pass through a US Standard 1-1/4 mesh sieve and less than $5 \mathrm{wt} \%$ passes through a US Standard 10 mesh screen. In addition, the cullet is free flowing and has a minimal number of strings or fibers.

\section{ATTACHMENTS}

1. Cullet Run Temperature Profile

2. Cullet Run Power Output

\section{REFERENCES}

1. T. M. Jones, D. C. Witt, CIM5 Job Plan to Flush Vessel With 25SrABS Glass From Frit and Marbles (U), SRT-AMC-99-0194, September 21,1999.

2. T. M. Jones, D. C. Witt, CIM5 TTR Run Plan \#1 - Produce Cullet From 25SrABS Marbles (U), SRT-AMC-99-0196, September 22,1999.

3. WSRC-NB-98-00227, 5" Cylindrical Induction Melter Development CIM 5 Laboratory Notebook. 


\section{Attachment \#1 - Cullet Run Temperature Profile}

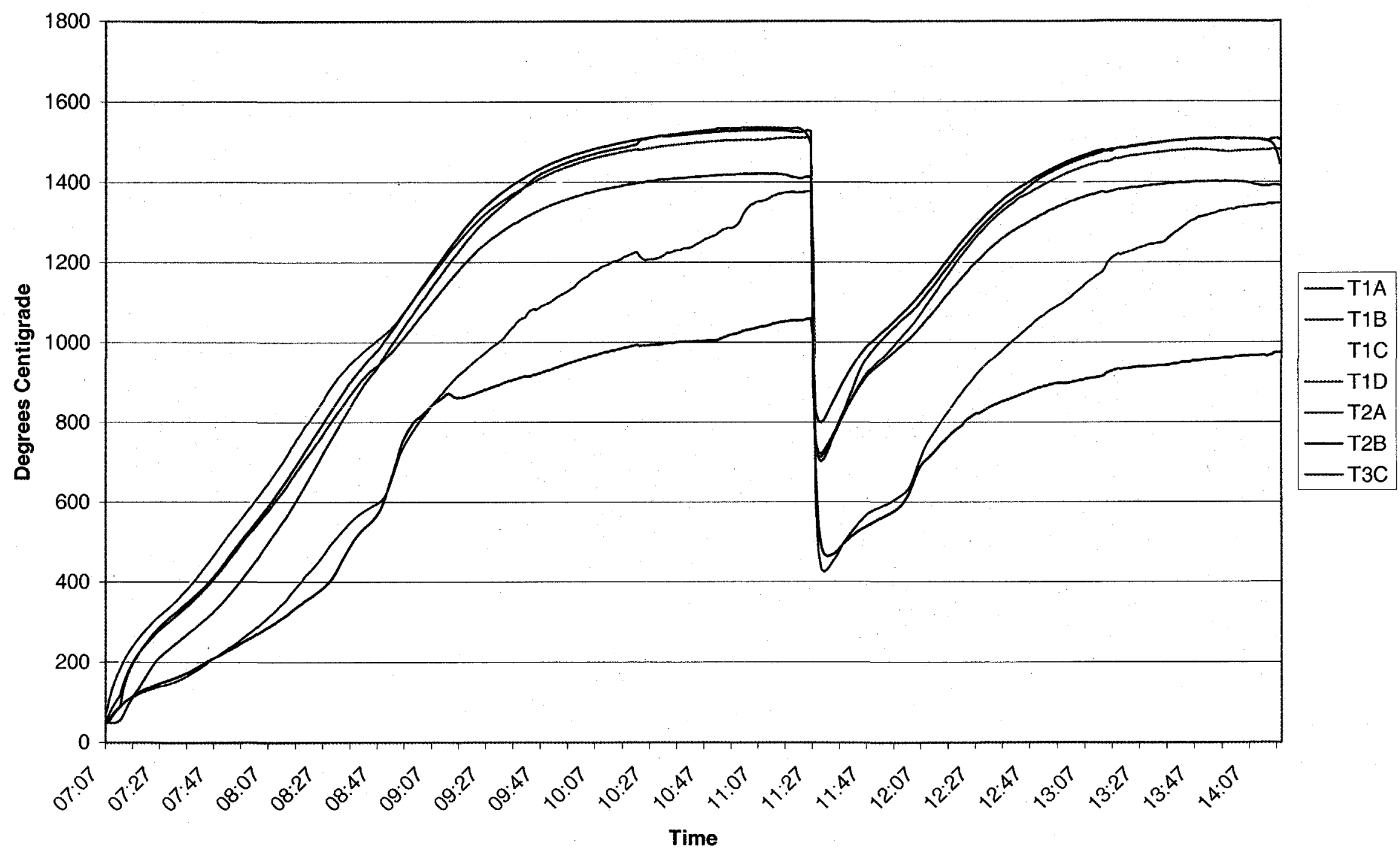


WSRC-TR-99-00466

Page 4 of 4

\section{Attachment \#2 - Cullet Run Power Output}

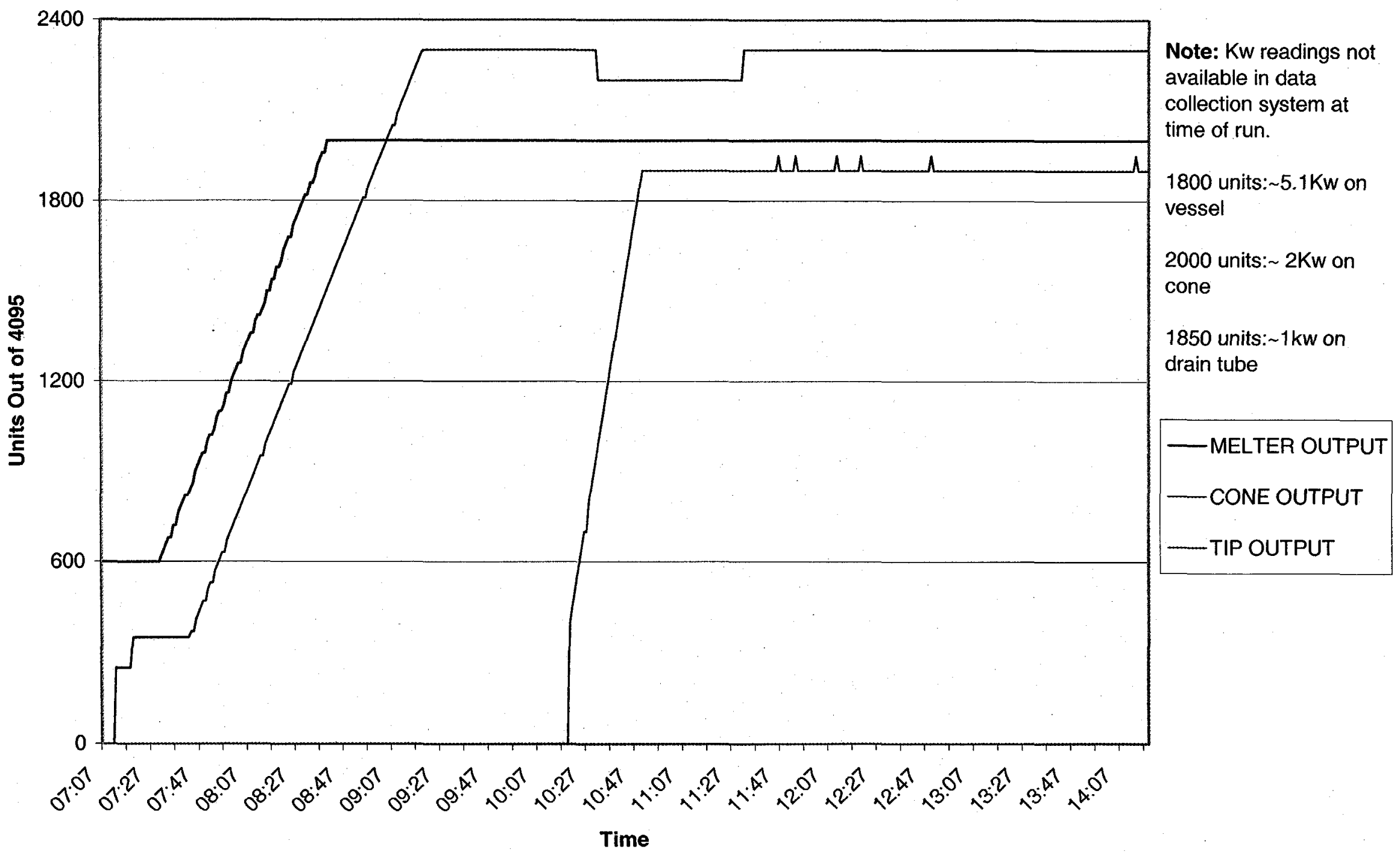




\section{DISTRIBUTION:}

L. M. Papouchado, 773-A

E. W. Holtzscheiter, 773-A

L. F. Landon, 704-1T

M. A. Baich, 704-1T

D. C. Witt, 704-1T

T. M. Jones, 704-1T

D. H. Miller, 704-1T

M. E. Stone, 704-1T

T. K. Snyder, 704-T

D. K .Peeler, 773-43A

C. B. Miller, 773-A

Am/Cm Files, 704-1T

STI, 703-43A (4) 